Article

\title{
From Waste Management to Component Management in the Construction Industry
}

\author{
Colin M. Rose ${ }^{1, *}$ (i) and Julia A. Stegemann ${ }^{2}$ \\ 1 Department of Civil, Environmental \& Geomatic Engineering, \\ Centre for Urban Sustainability and Resilience, University College London, Gower Street, \\ London WC1E 6BT, UK \\ 2 Department of Civil, Environmental \& Geomatic Engineering, \\ Centre for Resource Efficiency \& the Environment, University College London, Gower Street, \\ London WC1E 6BT, UK; j.stegemann@ucl.ac.uk \\ * Correspondence: colin.rose.13@ucl.ac.uk; Tel.: +44-773-647-5214
}

Received: 22 December 2017; Accepted: 15 January 2018; Published: 17 January 2018

\begin{abstract}
The construction industry uses more resources and produces more waste than any other industrial sector; sustainable development depends on the reduction of both, while providing for a growing global population. The reuse of existing building components could support this goal. However, it is difficult to reclaim components from demolition, and materials remain cheap compared with labour, so new approaches are needed for reuse to be implemented beyond niche projects. This study therefore reviews waste interventions. Multiple case studies, spanning new builds and refurbishment, were undertaken to examine systemic mechanisms that lead to components being discarded. Evidence from fieldwork observations, waste documentation, and interviews indicates that the generators of unwanted components effectively decide their fate, and a failure to identify components in advance, uncertainty over usefulness, the perception of cost and programme risk in reclamation, and the preferential order of the waste hierarchy mean that the decision to discard to waste management goes unchallenged. A triage process is proposed to capture timely information about existing building components to be discarded, make this information visible to a wide community, and determine usefulness by focusing creativity already present in the industry on an exhaustive examination of component reusability and upcyclability.
\end{abstract}

Keywords: reuse; building materials; construction and demolition waste; architecture; engineering; and construction (AEC) industry; end-of-waste; repurposing; upcycling; creativity; utility

\section{Introduction}

The global construction industry uses around $23 \mathrm{Gtpa}$ of non-fuel raw materials [1]. Extraction of these resources causes environmental damage, loss of habitat and biodiversity, and changes in land use patterns [2]. Processing and transporting those resources to supply useful building materials depletes reserves of non-renewable energy, and, in the UK, represents $8 \%$ of total greenhouse gas emissions [3,4]. At end-of-life, a large proportion of these resources become waste, with additional environmental impacts (Figure 1). Construction activities are responsible for $9 \mathrm{Gtpa}$ of waste globally [1], and one-third of total waste generation across EU countries [5].

The European Commission Waste Framework Directive [6] embeds into law the waste hierarchy's preferential order for waste management: after prevention, direct reuse of a product, then recycling (reprocessing into new products), recovery (such as generating energy through combustion), and, lastly, disposal. Member States are required to achieve a 70\% landfill diversion rate by 2020 for all construction and demolition (C\&D) waste except natural soil and stone and hazardous waste ([6] Article 11). In the UK, this target has been met: the statutory requirement for Site Waste Management Plans 
(SWMPs; repealed in December 2013), along with a voluntary initiative led by WRAP, Halving Waste to Landfill, the Aggregates Levy, and the gradual escalation of the Landfill Tax, have been effective levers in increasing the diversion rate [7]. Around the turn of the millennium, $45 \%$ of all C\&D waste was recycled [8]; by 2014, the figure had risen to 90\% [9]. BRE's SMARTWaste data [10], derived from thousands of individually reported projects, indicated a recycling rate of $91 \%$ in 2012. However, national and EU legislation does not set separate targets for reuse and recycling, and the main route for waste streams diverted from landfill has been recycling into lower value products-downcycling—often in an open loop.

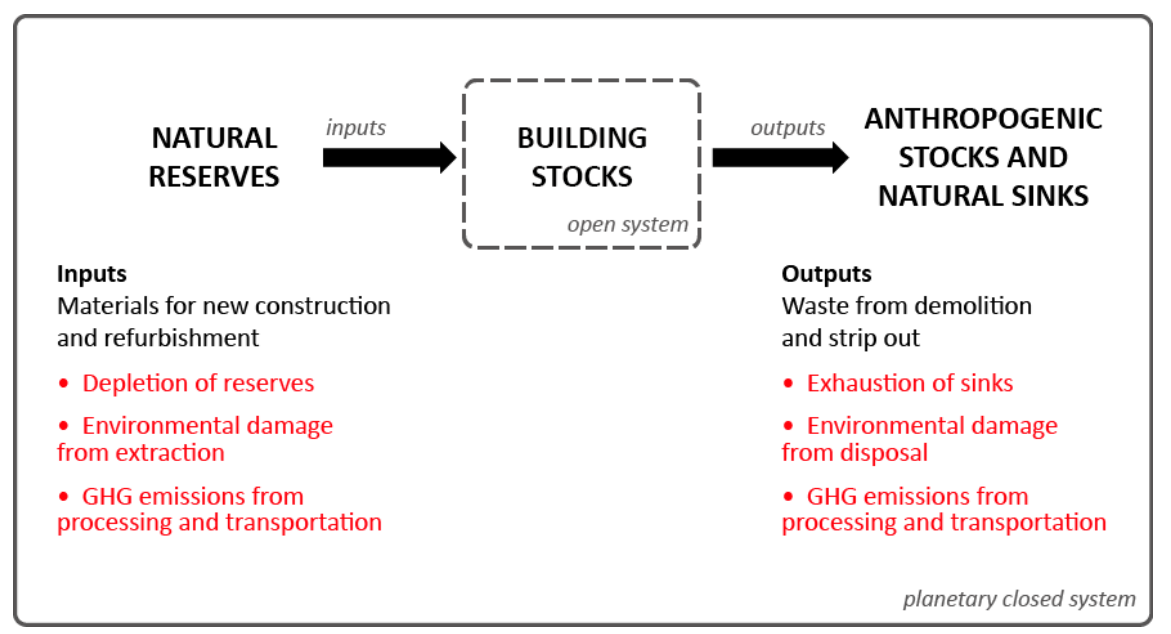

Figure 1. Simplified construction material flows and stocks, and the broad categories of their global environmental impacts shown in red. No impacts are noted for building stocks, as the material changes of repair and upgrade are captured under the flows in and out. The operational greenhouse gas (GHG) emissions of the existing building stock are considered outside the present scope.

There is a danger in assuming that the impact of construction waste has been successfully mitigated as recycling rates rise above $90 \%$. A first problem is that these data are based on whether waste is sent to recycling companies, rather than whether it is recycled in reality. Secondly, the impacts of transportation and recycling processes can be considerable. Thirdly, recycling processes can be highly wasteful. The global image of recycling-the familiar triangle of arrows-conjures an idea of continuous cycles, yet open-loop recycling is better described as delayed disposal [11]. When, for instance, timber joists are chipped for chipboard, this open-loop recycling still requires trees to be felled, milled, and produced when we want new joists. The recycled wood chip has a lower economic value than the joist from which it came. It also has reduced 'utility', considered as a function of the displaced impacts of extracting and processing a primary material, and the performance of that material's duty through a period of time. A chipped joist only displaces new wood chip (e.g., from forest thinnings), a material with low impacts. In products like chipboard or animal bedding, it can perform a duty for a limited period of time, and will be buried or incinerated relatively soon. A joist retained in its existing form may be able to displace new, kiln-dried sawn wood, and perform the duty of supporting a floor for many decades.

Utility also drops in the case of end-of-life concrete. Recycled aggregate from concrete displaces primary aggregate-a material with low value and impacts compared with concrete. The lower duty performed as aggregate represents a loss of between 70 and $185 \mathrm{~kg}$ embodied $\mathrm{CO}_{2} /$ tonne of concrete [12]. Even recycling of metals entails a loss of utility. Properties of products from refining steel scrap, for instance, do not match those of steel obtained from virgin production, so secondary steel is used for reinforcing bar and sections, but not for higher grade and applications like plate and sheet, which have greater impacts [13].

Schut et al. [14] report that, in the Netherlands, only 3-4\% of material used in the construction of buildings is from a secondary source, despite $95 \%$ of C\&D waste being recycled. A large proportion 
of this recyclate becomes fill in road construction. The environmental impacts of waste generation are thus reduced. However, the failure to retain materials as high-utility construction components means that the industry's enormous resource extraction continues more or less unabated. Current systems of waste management do not satisfactorily support mitigation of the construction industry's environmental impacts.

This article therefore reviews areas of waste interventions that seek to address these impacts. It then aims to explain the systemic mechanisms that currently lead to end-of-use building components being discarded as waste, and, in response, describe a series of interlinked activities to support (a) the identification and separation of reusable components, and (b) an incremental increase in the capacity for component management. The empirical research is based on case studies related to housing regeneration in the London Borough of Tower Hamlets, i.e., an urban environment in the UK.

The study finds that the decision to discard components to waste management frequently goes unchallenged, and that this is underpinned by, inter alia, a failure to identify components in advance and an acceptance of the preferential order of the waste hierarchy where direct reuse appears impractical. The generators of unwanted components effectively decide their fate, but these organisations are ill-equipped to answer the fundamental question of whether components are of use to others. A 'triage process' is proposed in which the onus for producing this knowledge is shared. Responsibilities for policymakers, clients, design teams, new upcycling enterprises, and academia are suggested, to reach a robust process for increasing diversion away from waste management and into component management.

\section{Review of C\&D Waste Interventions}

To address the global impacts shown in Figure 1, attention can be focused on three areas: (1) design of new additions to stock, (2) management of existing building stocks, and (3) maintenance and enhancement of the utility of removals from stock (Figure 2). A brief review of these areas follows, providing a demarcation of the scope of this study and a rationale for its focus on the third.

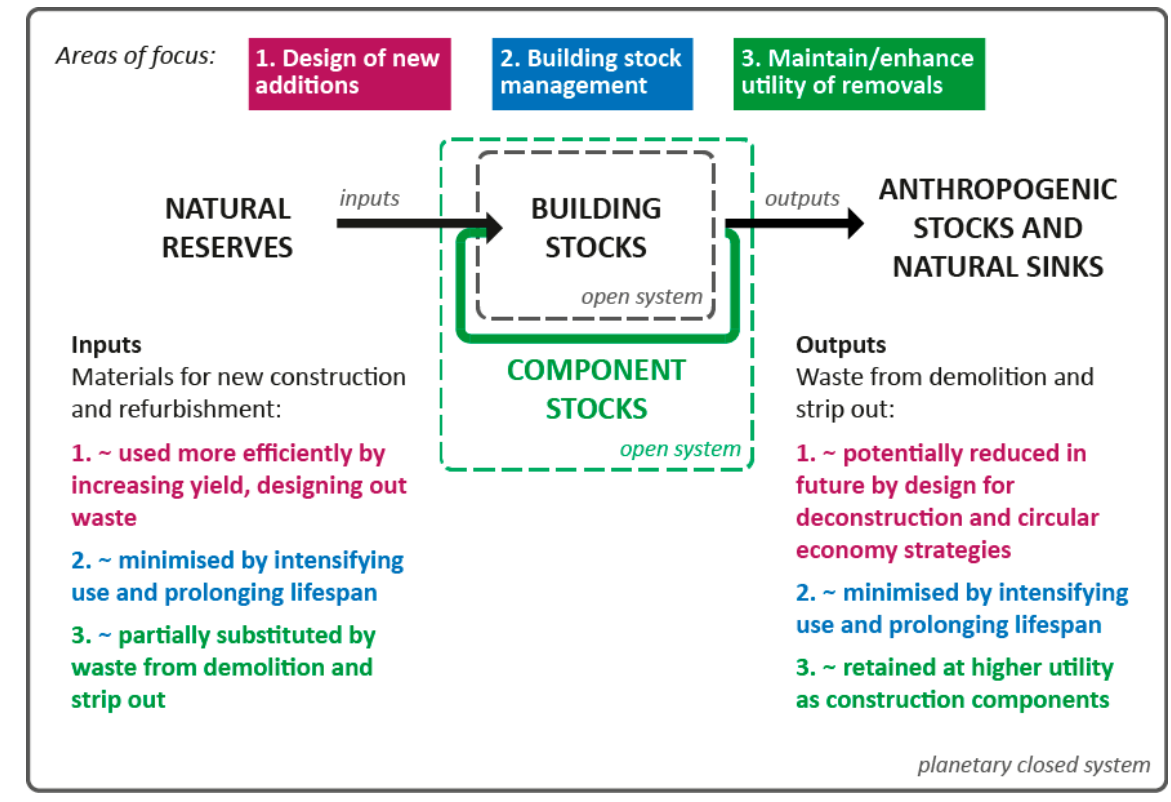

Figure 2. Three areas of focus in addressing waste and material efficiency in construction: (1) design of new additions to stock, (2) management of existing building stocks, and (3) maintenance and enhancement of the utility of removals from stock. The focus of the present research is area (3). Improvements to (3) can improve additions to stock (green arrow), but (1) does not rely on the use of secondary components and is described as an independent area of intervention. 


\subsection{Design of New Additions to Building Stocks}

Ways of reducing resource extraction and process waste by the design of additions to stock include the following: (a) in production, increasing the yield of useful materials from extracted resources [13]; and (b) in building construction, adopting various measures to reduce material inputs and 'design out waste' [15], such as off-site prefabrication, just-in-time delivery, and protection of goods on site [16]. These practical measures have been thoroughly covered in the literature $[17,18]$; more recently, there has been a focus on waste minimisation through the use of building information modelling (BIM), inter alia, to coordinate and validate design ahead of construction [19-21].

Reduction of future material inputs and waste outputs is an important aspect of the design of new additions to stock. Approaches in this mould have recently become associated with the idea of a circular economy. This encompasses a range of strategies [22] that aim to take control of the end-of-life scenario, by encouraging greater consideration of the whole life cycle at the design stage. Circularity in relation to the built environment (e.g., [23-26]) harnesses the established field of design for deconstruction (DfD; e.g., [27-29]). A change of perception is pursued, in which we see 'buildings as material banks' $[23,30]$, and actively manage accounts of the materials deposited within them through material passports, Internet of Things devices, and BIM [24,31-33].

While most circular economy thinking is focused at the individual product level, buildings are compositions of numerous products with different lifespans [34], which may be altered in a number of ways, from routine maintenance to structural adaptation. These factors mean that buildings are complex entities, and represent a different challenge to that of individual products [25]. Circular economy models are yet to reach widespread application beyond specific components that are easily removed and need frequent replacement, such as lighting [35] and carpet tiles [29]. Such ongoing contractual arrangements between building owner and manufacturer have great benefits in forcing engagement with future end-of-life. Their suitability to longer-lived components is less clear, given the likelihood of manufacturers ceasing trading before the circle closes [14].

Given that stock turnover is low (e.g., new build rates in the UK, Germany, Denmark, and the Netherlands are between 0.5 and 1.5 percent per year [36-38]), the segment of total stock improved by design changes would be relatively modest [39] even if all new buildings were built according to DfD and circular economy principles. The value of the envisaged life cycle improvements will not be realised for decades to come, and, as with any anticipation of future benefits, both the value and the timeframe naturally carry a level of uncertainty [40]. Over a building's lifespan, developments in materials, regulations, construction methods, and societal needs can create functional obsolescence of deconstructable buildings and reusable components; unexpected damage or wear can reduce integrity; tastes can change. A technical solution to building deconstructability and component reusability unfortunately will not ensure actual reuse [25].

A focus on additions to stock is justifiable, but by itself is not enough. It has no effect on today's waste generation; it overlooks the materials in our existing building stock and the resource this represents [41], which instead is seen as 'waste in waiting' [42].

\subsection{Management of Existing Building Stocks}

The most significant decision in relation to the generation of waste and use of materials is whether to demolish an existing building, whereby 'the most environmentally benign building is the one that does not have to be built' [43]. Management of the existing building stock, through intensifying use and prolonging lifespan [1], minimises the magnitude of resource inputs and waste outputs. However, the decision not to prolong lifespan, but instead to demolish, may be taken before the end of a building's physical service life [44,45] for reasons that are outside the control of the construction industry [46-48]. Factors that tend to influence this decision, such as land value and rental yield, are not within the present paper's scope.

Even if building lifespans are maximised, there will still be cases in which demolition (or deconstruction) is the only feasible option, as well as existing building components emerging from refurbishment. 


\subsection{Maintaining and Enhancing Utility of Removals from Stock}

Apart from downcycling, attention to materials removed from existing building stocks is presently limited to the architectural salvage industry, which provides some opportunity for contractors and demolition contractors to reclaim and sell building components. However, given the limited and fragmented nature of this market [49], its use depends to a large extent on the ability of contractors to maintain a network of organisations to whom they can sell materials that they would otherwise pay to discard [50]. These business networks will inevitably be bounded by circumstances such as the availability of nearby traders of a particular component type, and contractor awareness of these traders. Evidence suggests that the UK salvage industry is in decline in terms of quantities stocked, total value of trade, and number of people employed in the sector [51].

This trend may be partly attributable to the fact that most buildings built from the mid-twentieth century onwards are not constructed in a way that gives high potential for component recovery [30]. As demolition of earlier buildings is relatively rare, some researchers have been tempted to dismiss existing buildings as a source of reusable components in their entirety (e.g., [30,52]). The time and space required to carefully dismantle and set aside materials for reuse means that deconstruction of existing buildings is usually prohibitively expensive [53] for all except the most valuable items. Where the UK salvage industry continues to exist, it trades in goods with a known market value, like architectural ornaments or timber floorboards of established historic merit, and sells to a limited market segment of heritage projects and private high-end residential projects [54,55].

To increase its impact, reuse needs to reach beyond the current scope of the salvage industry. Many interrelated factors create drivers or barriers to the adoption of unconventional approaches in construction [56]. In the case of reuse, uncertainties over lead-in times, cost, and consistency of quantity and quality appear to be severe constraints on demand from risk-averse mainstream construction [57]. Lack of opportunities to purchase (e.g., a functioning market for secondary materials other than architectural salvage) may mean that demand is unknown [58]. Without demonstrable demand, a perception may develop that only goods traded by the salvage industry are reusable, such that there is rarely motivation to shift away from established demolition practices to careful deconstruction and reclamation [59,60]. The majority of removals from building stock therefore enter waste management, geared towards material recovery through recycling, and energy recovery through incineration. These processes are justifiably well-covered in the literature (e.g., [61-63]). Options for the viable recovery of component function, by contrast, remain limited $[57,64,65]$.

A shift from waste management to 'component management' may be afoot in certain material groups. Growing academic attention has focused on the reuse of structural steel, thanks to steel's ubiquity, the significant environmental benefits that would arise from shortcutting recycling, and the intuitive feasibility of deconstructing and reusing these relatively high-value components. The literature identifies barriers and constraints; looks at cases of successful reuse to determine whether barriers are real or perceived; finds the economic case marginal; and proposes systemic and technical interventions to encourage a more effective supply chain [32,66-73].

The economic challenges seen in the case of structural steel, and the narrow scope of products traded by salvage yards, suggest that a like-for-like model of reuse (e.g., timber floorboards reused as timber floorboards) is only viable for a select few building component types. Effective management of other less-valuable components may be supported by processes that not only retain their utility, but enhance it, to add value. Research exploring value-adding possibilities beyond like-for-like reuse is presently scarce, while research into systemic change in this area appears only sporadically.

\subsection{Creating More Opportunities for Reuse, Repurposing, and Upcycling}

In a 1994 interview, Reiner Pilz said: "Recycling, I call it down-cycling. They smash bricks, they smash everything. What we need is up-cycling, where old products are given more value, not less." [74]. Upcycling is generally understood to refer to the enhancement of value or utility through non-destructive recycling. Unlike direct reuse, some processing is undertaken (for instance, in the 
form of removing parts or joining components together), but it is not a destructive process that returns the component to raw material [75]. The impacts of a process must, to qualify it as upcycling, be less than the impacts of extracting and processing the virgin material displaced by the upcycled product. A waste stream transformed and repurposed such that it can perform a duty typically undertaken by a different type of virgin material with greater impacts can be understood to have increased in utility.

The role of upcycling in industry is garnering increasing attention [76]. Individual instances of enterprises developing new upcycling processes using C\&D waste have been reported [77,78], and there are examples of building projects that include repurposed and upcycled elements [79]. However, these cases are rare and are brought about in niches away from 'normal' markets [80]; there is little research on the conditions that might generate many more such innovations or bring their perceived benefits to bear on the mainstream construction industry.

Visions of systemic change have tended to look for means of stimulating new markets in reused components by creating information flows between 'supply projects' and potential 'demand projects'. As early as 2003, web-based waste exchange frameworks to improve the planning of demolition [81-84] were being investigated. Around the same time, Hurley proposed a 'material recovery notes' system (extending the idea of packaging recovery notes) to aid in the trading of end-of-use building components [85]. Chen et al. simulated an e-commerce system for the exchange of C\&D waste which they termed 'Webfill' [86]. Poelman also articulated the criticality of extracting information from the supply side and envisaged a system of 'Supply Driven Architecture' in which reusable materials in buildings are assessed, and the information is made available to architects [39]. Without reference to these precedents, Ali diagnosed a similar problem and elaborated another information exchange system, a 'Virtual Repository', with GIS (geographical information system) mapping and newly-prevalent BIM as the platform to allow the comparison of materials available from demolition or stored in salvage yards against those needed in new construction [87]. Ratman-Kłosińska proposed a 'StockExchange' for C\&D waste, with an associated directory of reuse actors [88]. Recently, Iacovidou and Purnell have described a 'typology system' to keep track of the properties of structural components through their lifecycle and enable their efficient use and reuse [49]. A current research project under the title 'Deconstruction and Recovery Information Modelling' aims to develop a tool for identifying reusable building components at end-of-life, for both new and existing buildings [89,90].

It is evident that related findings, ideas, and approaches arise intermittently in this area, but the various propositions lack a shared vocabulary and often do not successively build on previous research. Despite these authors' valuable contributions, practical implementations of what might be termed reused materials marketplaces (RMMs) have yet to provide a feasible alternative to conventional supply chains in mainstream construction. The small number of items available through UK examples of RMMs (e.g., [91-95]) demonstrate their low uptake.

The existing literature thus agrees on the need for better information about existing building components and marketplaces for their exchange. The assumption is that this will allow contractors and demolition contractors to understand where there is demand for items they would otherwise discard, and initiate reclamation and resale. However, the provision of information and role of marketplaces have not been conceived within a wider framework of activities that would be necessary to challenge existing practices and bring about significant change.

\section{Methods}

\subsection{Multiple Case Study Approach}

The project aim was pursued through multimethod qualitative case study research conducted with two housing organisations. The research was undertaken with a critical realist perspective [96]. Six live projects were chosen as case studies: one large-scale new build (construction cost $>£ 30 \mathrm{~m}$ ); one small-scale new build including demolition $(<£ 10 \mathrm{~m})$; three widespread refurbishment packages including strip-out (each $>£ 30 \mathrm{~m})$; and one smaller refurbishment package $(<£ 10 \mathrm{~m})$. 


\subsection{Sources of Evidence}

Case study methodologies encourage the triangulation of sources of evidence to increase internal validation of data and accuracy of observations [97]. The scientific method was organised around three main sources of evidence [98]:

1. fieldwork observations on construction sites and through regular visits to the waste transfer stations (WTSs) used in the case study projects, reported in Section 4.1;

2. documentation, which was largely in the form of contractors' SWMPs and waste reports, reported in Section 4.2; and

3. in-depth semi-structured interviews with 21 interviewees from the contractors, waste management companies, and members of the two client organisations (Table S1), reported in Section 4.3. Although an interview length of at least $60 \mathrm{~min}$ was sought for in-depth investigation [99], the average length was $48 \mathrm{~min}$.

\subsection{Data Analysis}

Raw data from interviews collated in a case study database were coded under emergent themes. Interviewees' testimonies on each theme were compared and contrasted, leading to the identification of a series of commonly reported issues and their possible underlying drivers (Table S2). These were analysed in the context of the literature review and other sources of evidence, in order to form explanations for the current situation (Section 5.1). Lastly, a systems engineering approach (based on [100]) was adopted in the development of an intervention in response to the findings (Section 5.2).

\section{Case Study Findings}

\subsection{Fieldwork Observations of CED Waste Logistics}

A picture of the steps by which C\&D waste is currently managed was built up based on direct observations in the field:

All case study projects except one employed a skip service. Typically, there is inadequate space on site to have different skips for each waste stream, except for the compulsory segregation of hazardous and non-hazardous waste, and metals that are generally separated at source and sold as scrap due to their value. The weighing of incoming skips and separation of waste fractions is undertaken at the WTS through a series of heavy plant operations, trommel screening, and manual sorting. The WTSs were all within $25 \mathrm{~km}$ of the construction sites.

WTSs are places of huge throughflow: waste carriers' vehicles will typically arrive every $2-5 \mathrm{~min}$. The operation only works, spatially and economically, if waste is continuously pushed through the system and out again, on the back of another truck, on to its next destination. Time and safety concerns prevent any manual sifting of reusable components from taking place, and, in any case, the sheer ruggedness of the environment means that good materials are unlikely to avoid damage.

Different waste fractions separated at the WTS travel to different destinations as their capacities and gate fees change, but haulage is a major cost so waste management companies seek to avoid large travel distances. In this study, the next destinations of waste fractions were within $75 \mathrm{~km}$ of the WTS. In the case of recyclables, these destinations were generally only the next link in a long chain of businesses involved in turning unwanted construction components into raw materials, for manufacture into a product with recycled content. This chain can extend to other parts of the UK, Europe, and-for metals, some plastics, and some cardboard packaging —worldwide.

\subsection{Documentation and Reporting of $C \mathcal{E} D$ Waste}

Although the UK's legislative requirement to carry out SWMPs has been repealed, in all cases the contractual arrangements between contractor and client continued to require them to be completed. However, the requirement to report on waste is typically fulfilled after-the-event by waste management 
companies. None of the contractors in the study collected their own data on quantities and types of waste arising, which is consistent with usual practice in this sector. None had carried out a pre-redevelopment audit [101] of materials that would emerge as waste from demolition and strip-out.

Waste is categorised by waste management companies based on European Waste Catalogue (EWC; [102]) codes, corresponding to the waste fractions that the company transfer away from the WTS (Figure S1). Waste management companies report back to their customers based on a record of the total quantity of each material processed at the plant. Typically, they assume that the waste profile of any given skip matches the profile of everything processed at the WTS (e.g., Figure S1a). Unless waste is segregated at the source, they are usually unable to report the actual quantities of each waste fraction received from any given project or contractor. Only one waste management company made visual assessments of skips' contents at the moment of tipping, to estimate by volume the proportion of different wastes received (Figure S1b). Some companies report only a total tonnage of 'mixed C\&D waste' (EWC code 1709 04). Thus, it can be seen that the information is retrospective; rarely specific to actual project or actual materials; classified into coarse categories; and directed at the contractor and client of the source project (rather than at any potential new users of the materials).

Combining all case study projects, a total of almost $95 \%$ of waste was reported as sent to recycling industries (Table S2), although the data do not account for the proportion of waste actually recycled downstream.

\subsection{Interview Findings}

The purpose of the interview process was to examine the roles and practices that frame the decision to reclaim and reuse or discard components to waste management. Attitudes and perceived constraints expressed in interviews are described by topic in Table S2 (column 3). These are interpreted in light of the authors' fieldwork observations (column 4), and underlying barrier and driver mechanisms and their causes are suggested (columns 5 and 6).

The client organisations in the case study projects did not instruct the reclamation of components from strip-out/demolition for reuse on site, so it was left to contractors to decide whether to deconstruct or demolish. Interviewees reported time, cost, and health and safety implications to deconstruction; the commercial benefits of resale were not apparent to them. Anecdotally, successful demolition contractors are very careful to identify components that they can reclaim and sell, as this represents their competitive advantage. However, in the case study projects-decommissioning of mid- to late-twentieth century housing and strip-out of elements within it for upgrading-demand for the components being produced was considered unlikely. The salvage industry was treated as a proxy for all market demand, and little emerges that would normally be seen in a salvage yard.

In this context, the assumption that components have no further use remains untested. The contractor lacks knowledge of needs beyond their current project and is not motivated or equipped to make a robust assessment of component usefulness. Their role does not normally involve product supply, and the idea that items they discard could be transformed for some new purpose did not occur in interviews without prompting. The use of RMMs to test demand and sell reclaimed components is not established practice. Those interviewees that were aware of their existence reported finding them inconvenient (time-consuming with low expectation of sales) or untrustworthy (typically selling to unknown individuals rather than to businesses). Interviewees could not imagine their own company using RMMs to purchase materials, due to non-compliance with client specifications, concerns over quality, and concerns over quantities available. Given that they do not perceive major consumers of building materials like themselves as potential customers, their scepticism about posting items to RMMs is logical. To do so is considered a positive, community-minded action, but not a viable alternative to conventional waste management. The skip service, by contrast, is simple, familiar, and reliable. Even though skip removal is perceived as expensive, gate fees are not so high as to incentivise widespread investment in alternatives. 
Two people at different waste management companies felt that the amount of good quality timber and plywood they see coming through their yards would, in their words, 'make you weep'. Indeed, a normative idea arose in several interviews, that those materials that can, should be used. This appeared to be a primary motivating factor for those contractors who had in the past found ways of passing on useful materials to the benefit of others, rather than any saving in disposal costs, or boost to their company's corporate social responsibility. Frequently, the default behaviour is to discard without considering reusability, but, in some cases, contractors' willingness to seek out alternatives is apparent. On those occasions, their intentions were often frustrated by the lack of a mechanism for bringing reuse connections to bear.

\section{Discussion}

\section{1. 'Where We Are': Systemic Mechanisms Leading to Components Being Discarded as Waste}

Drawing on the three sources of evidence, the system of waste management observed in the case study projects is illustrated geographically and logistically in Figure 3, and findings are synthesised in the following discussion.

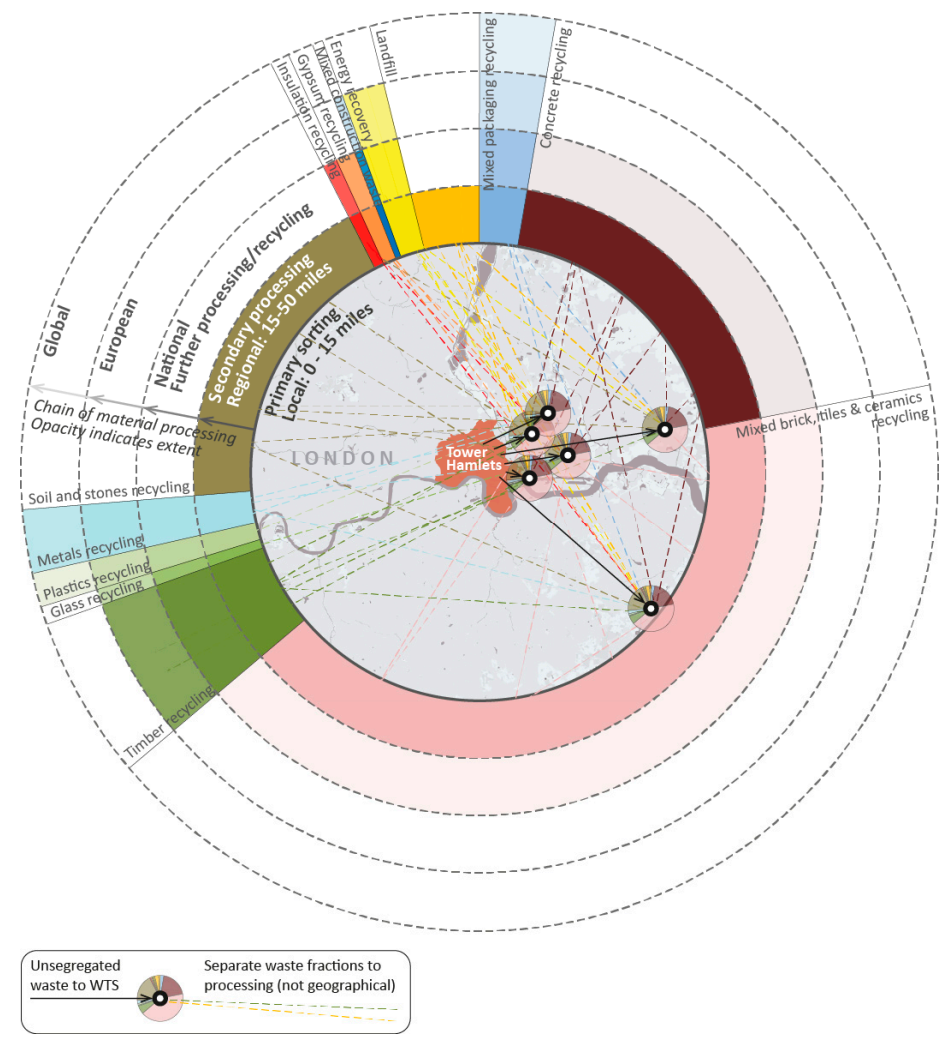

Figure 3. Diagram illustrating existing waste management logistics from case study projects. The map in the centre shows the area of London from which unsegregated site waste originated and the locations of waste transfer stations (WTSs). Arrows indicate the transfer of waste from construction sites to WTSs, and their links to onward waste processing. In the rings outside the map, the angle formed within a sector indicates the material's proportion of total waste reported across all case study projects, and the opacity of the sector in each ring indicates the geographical extent of the material's processing. Thus, the metal sector reaches as far as the outer ring at almost full opacity, because the majority of metal recycling happens beyond Europe.

There is a mature infrastructure underpinning the chains of recycling and energy recovery mapped in Figure 3; the economic value of feedstocks is understood through the network and fees payable by contractors and waste management companies are reasonably predictable. By comparison, the case study projects exhibited no examples of reuse and little connection to the salvage industry or any 
other reuse infrastructure. This absence makes it difficult to evaluate whether reclamation will be cost-effective. Discarding components to waste management is perceived as a safe, default position that was unchallenged in all case study projects (Figure 4a). This perception that components are unwanted and valueless sets in motion a series of steps from which it is difficult to recover any component utility. Components are treated as a liability rather than an asset, undergoing destructive demolition rather than careful dismantling. Contractors do not see value in creating the capacity to take a proactive role in sorting and redistributing these materials: instead, the skip service provides a simple release valve. Once discarded to a skip, they are 'waste', subject to further damage and mixed with other wastes. WTSs provide the interface with the rest of the waste management infrastructure, but are not set up as places for reclamation. By the time waste has reached the WTS, therefore, the management options are effectively limited to recycling, incineration with or without energy recovery, and landfill. If building components are to be reclaimed, demand must be recognised from the outset. To establish whether there is demand requires timely and appropriate information about existing building components. Nascent systems of component management are illustrated in Figure $4 b, c$, in which an audit provides the starting point. This could be in the form of a pre-redevelopment audit, or informal identification of reusable components, such as the practical knowledge that a demolition contractor may apply when tendering a job.

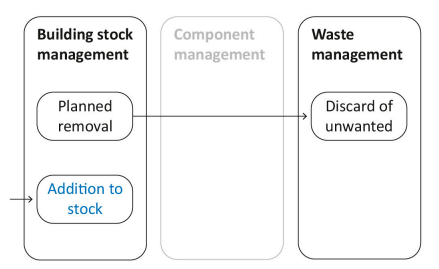

(a)

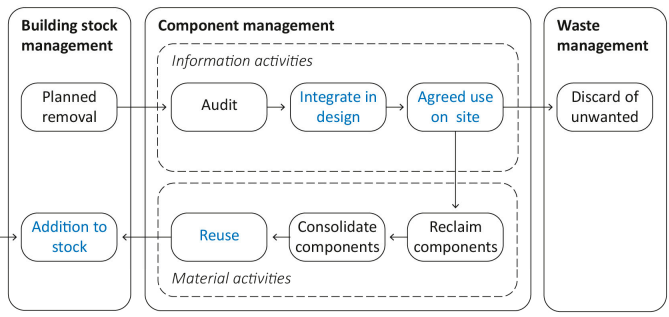

(b)

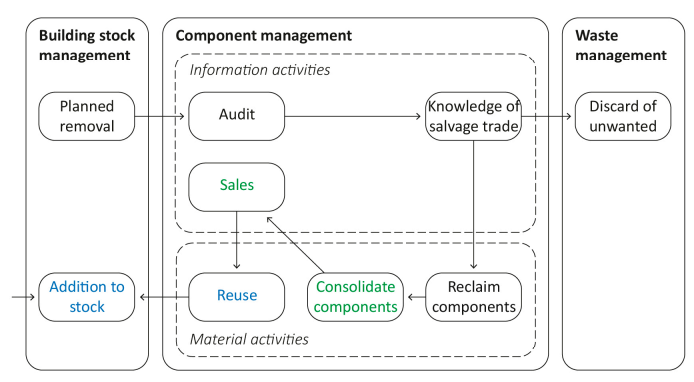

(c)

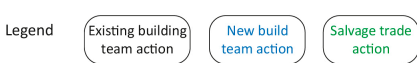

Figure 4. Current scenarios for the sequence of activities that determine treatment of existing building components: (a) no consideration of potential to retain component function-complete reliance on waste management, as seen in the case study projects; (b) nascent component management-formal or informal audit and engagement of new build team, allowing potential for some secondary use on site, as reported, e.g., in [103]; (c) nascent component management-formal or informal audit and knowledge of salvage traders, leading to some reuse off site. Combined use of $(\mathbf{b}, \mathbf{c})$ represents current best case scenario, with continued reliance on waste management for the majority of components removed from stock. 
The primary source of information about materials emerging from the case study projects was waste reporting. As well as being generated too late in the process, these reports do not provide a qualitative understanding of components that would be necessary in identifying demand. EWC codes or the categories of the European Waste Statistics Directive (EWC-Stat; [104]) capture all types of waste, but do so in a way that is geared towards waste management, rather than component utility, despite the intention of aiding waste prevention. Taking an example, there are only two EWC codes for timber construction waste: 170201 (wood), and 1702 04* (glass, plastic, and wood containing or contaminated with dangerous substances). The codes do not distinguish between a solid timber joist, a kitchen unit of chipboard and melamine, and a panelled door: distinctions that would need to be drawn in order to understand whether such components can serve others' needs. The point is demonstrated by Figure 5: a 'soil and stone' pile with large blocks of cut granite in amongst soil and gravel. All are ' 170504 ' as far as the EWC is concerned, and all attract the lower UK landfill tax rate for inert waste, but are very different in terms of embodied carbon, utility, and value. Measuring in terms of undifferentiated tonnage or volume of broad waste categories biases their disposal towards downcycling en masse.

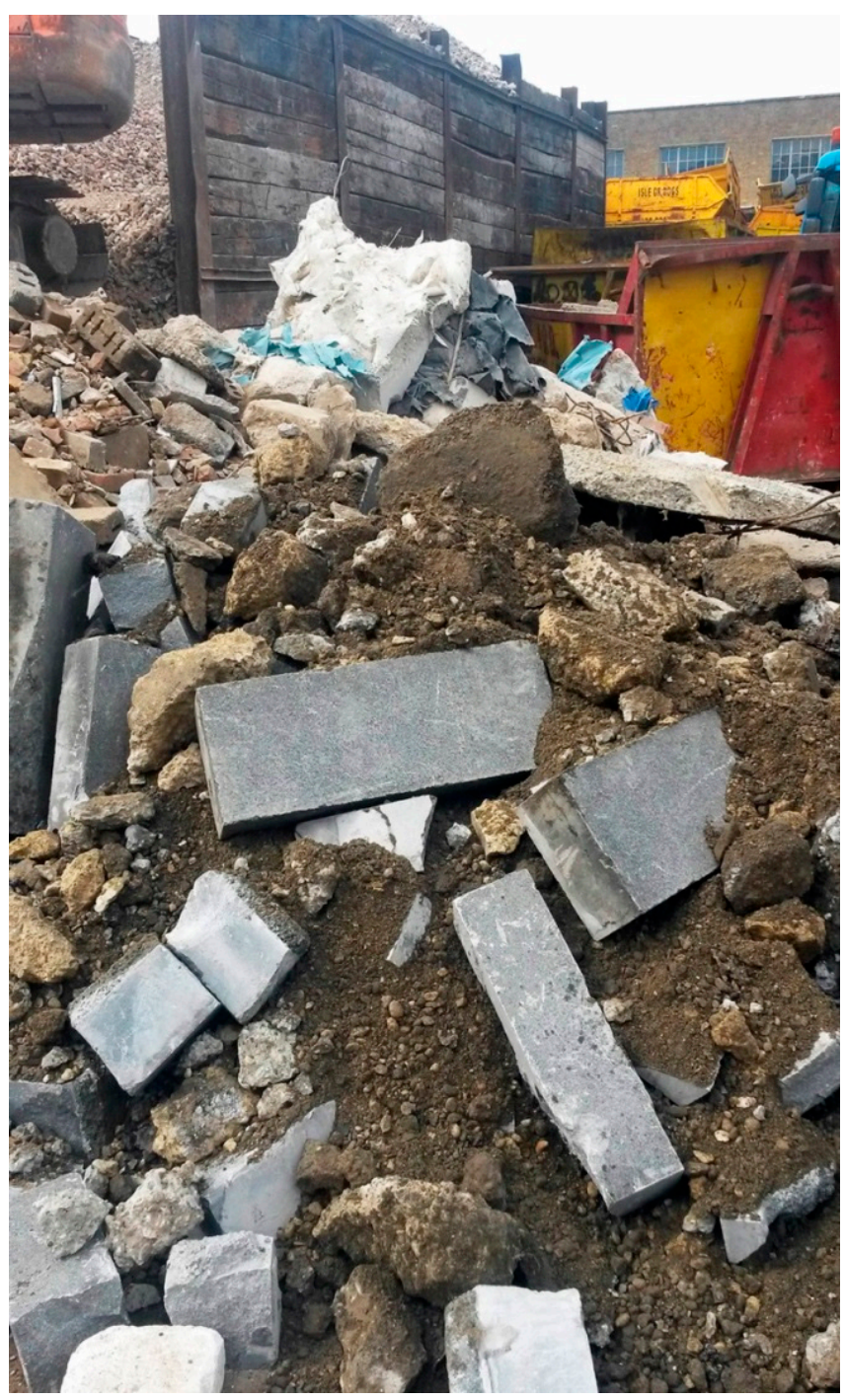

Figure 5. Soil and stone pile at WTS (European Waste Catalogue (EWC) code 1705 04): inadequacy of codes in differentiating utility. 
A detailed understanding of specific building components is not necessary for them to serve as feedstock for conventional recycling, because they will be returned to the state of raw material. This loss of specificity means that recycling can provide certainty over future (albeit lower) utility [68]. The utility of a specific reclaimed component, with its idiosyncrasies, is far less clear-cut. Individuals from the contractor and the design team will have an intimate awareness only of the needs of their current project, or a handful of projects in which their company is involved. Thus, there is a vantage point problem in the scenarios illustrated in Figure $4 \mathrm{~b}$,c: those faced with deciding components' fates do not have the vantage point to see other projects that might be able to use them. This interpretation is consistent with reports in the literature: the proportion of components successfully reclaimed and reused remains low, even in the best case of thorough auditing $[103,105]$.

RMMs hold promise in addressing the vantage point by creating a flow of information between supply and demand. This study suggests that the limited uptake of RMMs is down to three main weaknesses. Firstly, items are usually offered at the time that they arise as waste, and this does not leave a period for architects and engineers to incorporate particular components into design development, or for buyers and sellers to negotiate a deal. Secondly, since most contractors do not consider using RMMs to post unwanted items, very little tends to be available. Thirdly, items may be offered without the warranties required by insurers [106], so although UK Building Regulations have a fitness for purpose clause that should facilitate the appropriate use of reclaimed materials, they are viewed with caution in mainstream construction [107]. Without sufficiently early information, adequate choice, and assurance over the quantity and quality of offerings, the ability to capitalise on RMMs is limited to small and informal demand projects that are less selective and can make immediate use of materials.

Given the vantage point problem and the limitations of RMMs, direct reuse connections often do not materialise. The waste hierarchy indicates that recycling (in any form) then becomes the preferred option, validating conventional waste management [108]. This could be seen as premature. The current system (a) does not allow the potential for direct reuse to be explored systematically, and (b) does not identify scope for remanufacturing and upcycling. These processes are potentially more practicable than reuse and environmentally preferable to downcycling, but are not supported by the waste hierarchy. The following section attempts to embed a thorough exploration of reuse and the overlooked possibility of upcycling into a system of component management.

\section{2. 'Where We Want to Be': A Triage Process to Support Reuse, Repurposing, and Upcycling}

Based on an analysis of $C \& D$ waste management processes, the previous section explained that for building components to be reclaimed, demand must exist and be identified from the outset; that to serve latent demand, specific components' qualities as well as quantities must be identified; and that to overcome the vantage point problem, this information must flow between supply and demand. It was noted, however, that the demand projects that can directly reuse components identified in this way are limited. For demolition practices to change (and thus increase the supply of reclaimed goods), there must be timely evidence of demand at scale. This section expands on the nascent model of component management illustrated in Figure 4 to address the identified needs and shortfalls. It describes a series of interlinked activities that are necessary to form a triage process (Figure 6) in pursuit of the aim of more comprehensive component management.

To enable exhaustive exploration of the potential for direct reuse, there is a need for effective information flows through a widely accessible database similar to an RMM. Figure 6a begins to address the identified shortfalls of RMMs by integrating an information gathering regime modelled on pre-redevelopment audits [101]. At present, the results of audits are used in isolation by the project team and only inform waste management decisions. If, instead, audits from many projects were collated in a database, with components that are to emerge as waste described systematically (and qualitatively as well as quantitatively), it would create a timely array of information. Potential demand actors could navigate the database online and agreements could be reached prior to strip-out, demolition, or deconstruction. 


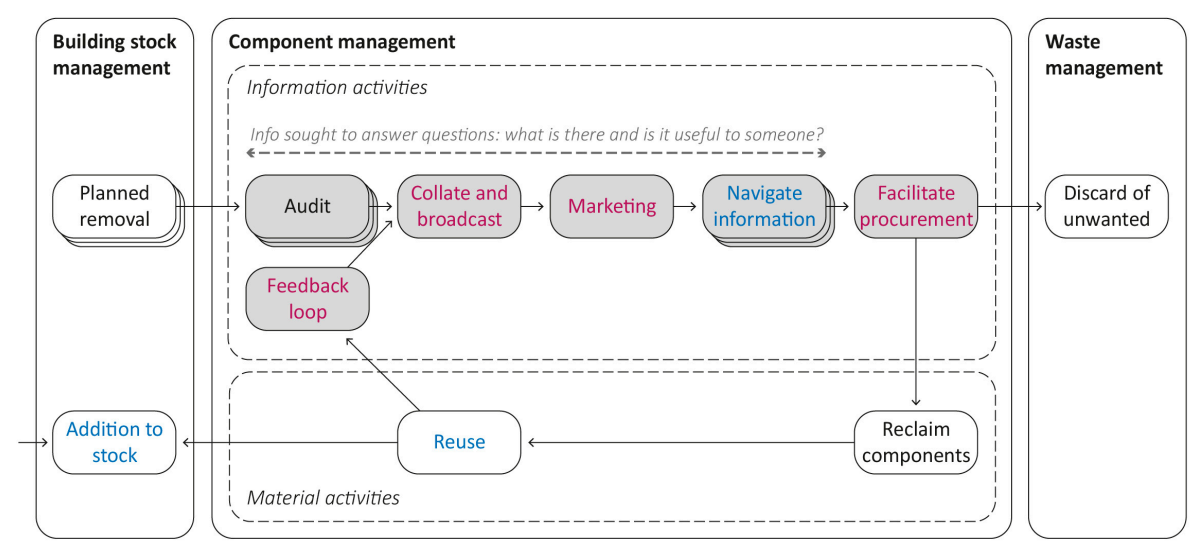

(a)

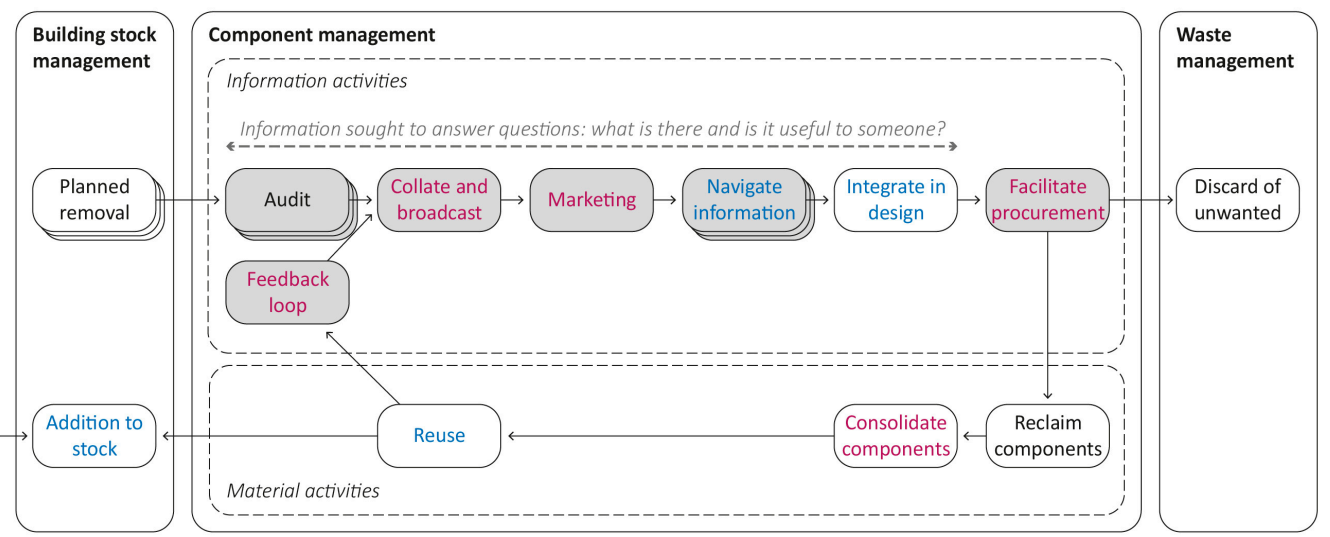

(b)

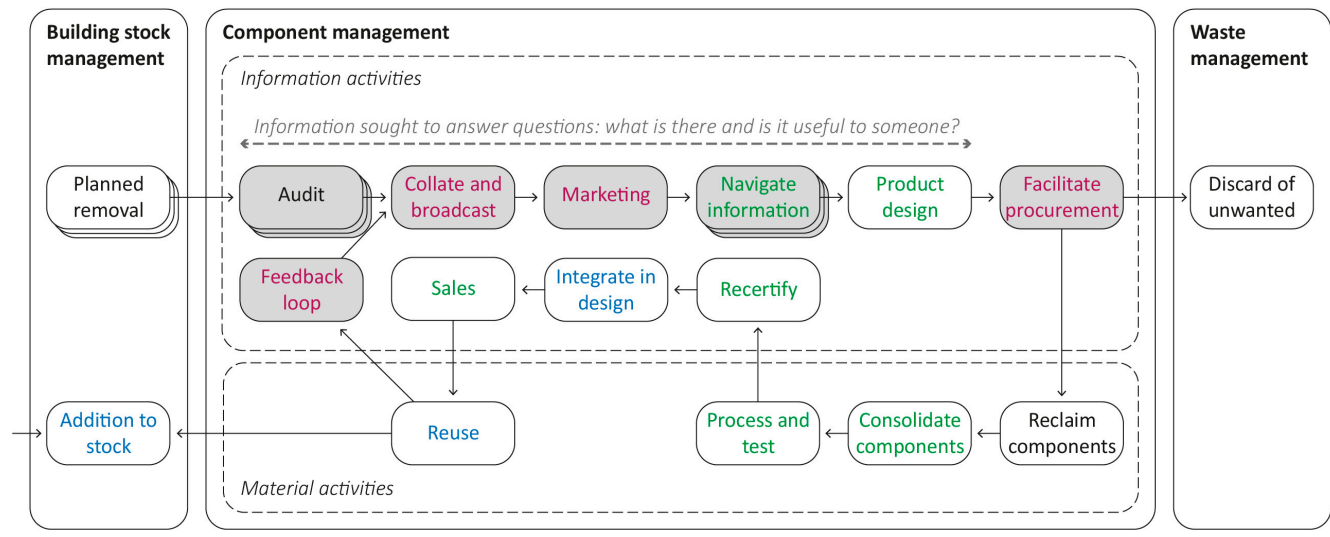

(c)

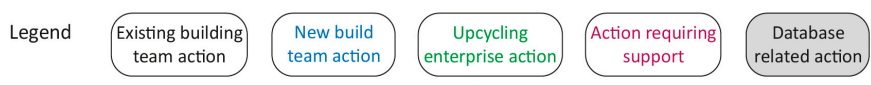

Figure 6. Proposed triage process comprising a series of activities that captures information about existing building components to be removed from stock; makes it visible to a wide community of contractors, designers, and businesses; and determines components' usefulness for: (a) direct reuse-simply substituting specified component for available reclaimed component; (b) direct reuse or repurposing included in design-increasing the scope for using reclaimed; or (c) feedstock for upcycling enterprise-manufacturing certified products that can be used like any other product.

Carrying out a pre-redevelopment audit is incentivised in BREEAM, the environmental accreditation scheme, although as a non-compulsory initiative, auditing is unlikely to become common practice until the benefits are made clear. Legislative change could kick-start this system, for instance, 
by requiring the submission of an audit for all developments seeking planning consent above a certain size threshold. Intervention at the planning stage ensures that the information is submitted and can be broadcast well in advance of starting on site: in the UK, the period between making a planning application and starting construction is rarely less than six months, and often far longer. Requiring an audit for all projects with significant strip-out or demolition would create a far larger variety and quantity of available components, and a more fertile database from which to meet a new project's needs. The development of standard clauses to enable the specification of items from this source would align reused components with conventional procurement.

The third problem with RMMs-uncertainty over the quantity and quality of offerings-is not addressed by the activities illustrated in Figure 6a. In this scenario, components are directly transferred from one site to another without consolidation or warranties, so demand will remain limited to small and informal projects. Introducing a consolidation activity in which components are stockpiled ahead of reuse (Figure $6 \mathrm{~b}$ ) can ensure that adequate quantities are available to meet a larger project's needs, and can help to reconcile project timing and delays [109]. Evidence from the salvage industry suggests that the consolidation and storage function cannot be performed profitably for the majority of component types in today's context. This would either need to be supported as part of public authorities' goals of improving the environmental impacts of construction, increasing urban management of a city's own waste, and creating additional employment (e.g., by allocating pockets of publicly owned land and resources to manage component storage); or the consolidation function would need to be carried out by private third parties that subsidise the cost of consolidation as part of a larger profit-making enterprise that may include upcycling, testing, and recertification (Figure 6c).

Such third parties between supply and demand may carry out only minor work, or they may undertake new processes not currently recognised as separate waste management options. Necessarily, they would add significant value to their feedstocks for their business models to be viable. It is the database that focuses the creativity of entrepreneurs, academics, and designers on the invention of new uses for existing building components. The emergence of upcycled and recertified products is the factor that could ultimately expand the remit of reuse beyond niche projects and into mainstream construction, allowing a far greater proportion of components to be retained locally at high value and utility. Costs and lead-in times would become more competitive with virgin products as flows increase [73].

This commentary must be seen in the light of the many barriers reported in the literature (e.g., [64,110-113]) which have at their root the relatively high price of urban land and labour in comparison to those of materials. Increases in virgin resource prices and price volatility may be forced upon the industry over time [114] or early correction of these rises to avoid 'hitting the wall' [115] may be brought about through tax reform. Many authors have investigated forms of increase in the taxation of non-renewable resources and reduction in the tax burden on employment in order to capture the negative externalities of resource use and encourage the use of the plentiful renewable resource of human labour [116-121]. The industrial establishment resists such measures, though landfill taxes provide a precedent for top-down government intervention bringing about widespread, positive change [75]. Regulatory drivers (such as limits on whole life carbon or measures to incentivise the use of materials with low embodied carbon) may also strengthen the economic case for component management. Until such changes are brought about, either proactively by governments, or passively by a shifting global economic context, stimulating reuse will remain a challenge.

To look at the economic situation another way, if these changes are considered inevitable in the long term, efforts now to evolve $C \& D$ waste management towards component management are a bulwark to the resilience of the construction industry, and to our future prosperity.

\subsection{Limitations and Further Research}

The analysis of case studies attempted to draw conclusions that hold true for C\&D waste management in urban environments. However, the critical realist philosophy adopted accepts 
that the particular phenomena under scrutiny and the conditions under which they arose are dynamic; interpretations are limited to their time and place and cannot necessarily be generalised to a wider context.

The potential of reuse to reduce disposal costs for waste generators and reduce material costs for new construction has not been adequately demonstrated. To increase confidence in the case for changing industry practices, or introducing legislation to kick-start component management, further research is required. This research could interrogate aspects of an effective system of component management, such as the nature of information required; means of efficiently gathering this data; and opportunities for adding value to specific waste streams through new upcycling business models. As an example, the authors are currently examining the manufacture of structural cross-laminated timber using waste wood as a principal feedstock.

\section{Conclusions}

The construction industry has made considerable progress in its management of waste since the 1990s, when disposal in landfill was common. However, the now-prevalent system of recycling does not capitalise on the value of existing components, and wastes embodied environmental impacts. Reuse, repurposing, and upcycling offer the potential to improve upon waste management, but the decision to discard components frequently goes unchallenged. This is underpinned by:

1. a failure to identify components in advance-current waste reporting is retrospective and classified in coarse material categories, is geared towards waste management, and does not identify specific components' qualities;

2. uncertainty over the utility or value of components to others-unlike recycling, reuse suffers from a vantage point problem of knowing what is of use elsewhere; as a means of overcoming this problem, RMMs have drawbacks that impede uptake;

3. a perception of cost and programme risk in undertaking reclamation-in the context of (1) and (2), an inability to assess the merit of reclamation; and

4. acceptance of the preferential order of the waste hierarchy-recycling (in any form) becomes the preferred option where direct reuse appears impractical, such that exploration of the potential for upcycling is not supported.

For contractors to reclaim a greater proportion of building components, demand must be identified from the outset, but contractors are ill-equipped to answer the fundamental question of whether components are of use to others. This paper therefore developed a 'triage process' in which the onus for producing this knowledge is shared.

Policymakers can kick-start the generation of relevant information at early stages of projects by requiring the submission of a pre-redevelopment audit for all developments above a certain size threshold seeking planning consent. Local authorities or service providers can develop and maintain a database in which the audit results are collated and broadcast. Clients and their design teams can use this database to identify and specify useful components well in advance of demolition. Researchers and entrepreneurs can use the database to identify underused components, for which environmental and economic improvements upon conventional recycling can be developed, and, in due course, deliver recertified upcycled products. Many of the risks and constraints associated with reused materials would be overcome by successful upcycling, allowing a wider array of clients, contractors, and designers to adopt their use. The triage thus provides a framework for the robust exploration of direct reuse, and focuses creativity already present in and around the construction industry on the invention of new uses for existing building components. In doing so, it contributes to an emerging system of component management, in which those components that can be retained for reuse are separated out from those for which waste management is the best option.

Supplementary Materials: The following are available online at www.mdpi.com/2071-1050/10/1/229/s1, Figure S1: Waste stream breakdowns for case study projects, as reported by waste management companies, 
Table S1: Summary of interviewees, Table S2: Total proportions of each waste stream and treatment method for all case study projects, Table S3: Summary of findings from interviews with contractors, waste management companies and client organisations.

Acknowledgments: This paper is based on research undertaken as part of the EPSRC project 'Developing systems to enable reuse of waste building components' (Grant Reference: EP/G037698/1); support by project collaborators Poplar HARCA and Tower Hamlets Homes is gratefully acknowledged. The authors would additionally like to thank the members of the contractors, waste management companies, and client organisations who agreed to participate in this study; and the reviewers for their constructive input.

Author Contributions: Colin M. Rose instigated the research project, carried out the empirical research and the theory development, and wrote the manuscript. Julia A. Stegemann supervised the project, contributed to the theory development and provided feedback on manuscript drafts.

Conflicts of Interest: The authors declare no conflict of interest.

\section{References}

1. Haas, W.; Krausmann, F.; Wiedenhofer, D.; Heinz, M. How Circular is the Global Economy? An Assessment of Material Flows, Waste Production, and Recycling in the European Union and the World in 2005. J. Ind. Ecol. 2015, 19, 765-777. [CrossRef]

2. Tukker, A.; Jansen, B. Environmental Impacts of Products: A Detailed Review of Studies. J. Ind. Ecol. 2006, 10, 159-182. [CrossRef]

3. Department for Business Innovation and Skills (BIS). Low Carbon Construction Innovation E Growth Team-Final Report; HM Government: London, UK, 2010.

4. Steele, K.; Hurst, T.; Giesekam, J. Green Construction Board Low Carbon Routemap for the Built Environment: 2015 Routemap Progress-Technical Report; Green Construction Board: London, UK, 2015; pp. 1-28.

5. Eurostat. Generation and Treatment of Waste in Europe 2008; Eurostat: Luxembourg, 2011.

6. European Commission. Directive 2008/98/EC of the European Parliament and of the Council of 19 November 2008 on Waste and Repealing Certain Directives (Waste Framework Directive); European Commission: Brussels, Belgium, 2008; pp. 3-30.

7. Hobbs, G. (Ed.) United Kingdom. In Construction Waste Reduction around the World; CIB Publication 364; International Council for Research and Innovation in Building and Construction (CIB): Rotterdam, The Netherlands, 2011; pp. 122-131, ISBN 978-90-6363-067-6.

8. Symonds Group Ltd. Construction and Demolition Waste Management Practices, and Their Economic Impacts; Report to DGXI; European Commission: Brussels, Belgium, 1999.

9. Department for Environment, Food and Rural Affairs (Defra). UK Statistics on Waste; Defra: York, UK, 2016.

10. BRE SMARTWaste Summary Data, Watford. 2013. Available online: http://pinpoint.ukgbc.org/resource/ 8142-bre-smartwaste-summary-data.php (accessed on 11 January 2018).

11. Anderson, C. Zero waste theory and practice. In Proceedings of the Philosophy and Waste: Building Bridges Graduate Conference, Carbondale, IL, USA, 4-5 November 2011.

12. Mineral Products Association. Whole-Life Carbon and Buildings: Concrete Solutions for Reducing Embodied and Operational $\mathrm{CO}_{2}$; Mineral Products Association: London, UK, 2016.

13. Allwood, J.M. Squaring the circular economy: The role of recycling within a hierarchy of material management strategies. In Handbook of Recycling: State-of-the-Art for Practitioners, Analysts, and Scientists; Reuter, M., Worrell, E., Eds.; Elsevier: Amsterdam, The Netherlands, 2014; pp. 445-477, ISBN 9780123965066.

14. Schut, E.; Crielaard, M.; Mesman, M. Circular Economy in the Dutch Construction Sector; Rijkswaterstaat WVL: Lelystad, The Netherlands, 2015.

15. Waste \& Resources Action Programme (WRAP). Designing out Waste Tool for Buildings; Waste \& Resources Action Programme: Banbury, UK, 2010.

16. Department for Environment, Food and Rural Affairs (Defra). Waste Strategy for England 2007, Annex C3: Construction, Demolition and Excavation Waste; Defra: London, UK, 2007.

17. Ferguson, J. Managing and Minimizing Construction Waste: A Practical Guide; Thomas Telford Ltd.: London, UK, 1995; ISBN 0-7277-2023-6.

18. Guthrie, P.; Mallett, H. Waste Minimisation and Recycling in Construction-A Review; Construction Industry Research and Information Association (CIRIA): London, UK, 1995; ISBN 0-86017-428-X. 
19. Liu, Z.; Osmani, M.; Demian, P.; Baldwin, A. A BIM-aided construction waste minimisation framework. Autom. Constr. 2015, 59, 1-23. [CrossRef]

20. Won, J.; Cheng, J.C.P.; Lee, G. Quantification of construction waste prevented by BIM-based design validation: Case studies in South Korea. Waste Manag. 2015, 49, 170-180. [CrossRef] [PubMed]

21. Waste \& Resources Action Programme (WRAP). Resource Efficiency through BIM: A Guide for BIM Users; Waste \& Resources Action Programme: Banbury, UK, 2013.

22. Lacy, P.; Rutqvist, J. Waste to Wealth; Palgrave Macmillan: Basingstoke, UK, 2015; ISBN 978-1-349-58040-8.

23. Debacker, W.; Manshoven, S. D1 Synthesis of the State-of-the-Art: Key Barriers and Opportunities for Materials Passports and Reversible Building Design in the Current System. 2016. Available online: http: / / www.bamb2020.eu/library/ (accessed on 11 January 2018).

24. Ellen MacArthur Foundation. Circularity in the Built Environment: A Compilation of Case Studies from the CE100. 2016. Available online: https:/ / www.ellenmacarthurfoundation.org/assets/downloads/BuiltEnv-Co.Project.pdf (accessed on 11 January 2018).

25. Pomponi, F.; Moncaster, A. Circular economy research in the built environment: A theoretical contribution. In Building Information Modelling, Building Performance, Design and Smart Construction; Dastbaz, M., Gorse, C., Eds.; Springer: Cham, Switzerland, 2016.

26. Zimmann, R.; O’Brien, H.; Hargrave, J.; Morrell, M. The Circular Economy in the Built Environment; Arup: London, UK, 2016.

27. Addis, W.; Schouten, J. Design for Reconstruction: Principles of Design to Facilitate Reuse and Recycling; Construction Industry Research and Information Association (CIRIA): London, UK, 2004; ISBN 0-86017-607-X.

28. Guy, B.; Shell, S.; Esherick, H. Design for deconstruction and materials reuse. In Proceedings of the CIB Task Group 39; Chini, A.R., Schultmann, F., Eds.; International Council for Research and Innovation in Building and Construction (CIB): Rotterdam, The Netherlands, 2002; Volume 39, pp. 189-209.

29. Morgan, C.; Stevenson, F. Design for Deconstruction-SEDA Design Guides for Scotland: No. 1; Scottish Ecological Design Association: Glasgow, UK, 2005.

30. Durmišević, E. Buildings as material banks. In Proceedings of the 3rd International Conference on the Importance of Place, Sarajevo, Bosnia and Herzegovina, 21-24 October 2015; Popovac, M.R., Idrizbegović-Zgonić, A., Klarić, S., Rustempašić, N., Čausević, A., Eds.; CICOPBH: Sarajevo, Bosnia and Herzegovina, 2015; Volume 2, pp. 139-152.

31. Luscuere, L.M. Materials Passports: Optimising value recovery from materials. Waste Resour. Manag. 2017, 170, 25-28. [CrossRef]

32. Ness, D.; Swift, J.; Ranasinghe, D.C.; Xing, K.; Soebarto, V.; Terziovski, M. Smart steel: New paradigms for the reuse of steel enabled by digital tracking and modelling. J. Clean. Prod. 2015, 98, 1-16. [CrossRef]

33. Heiskanen, A. The technology of trust: How the Internet of Things and blockchain could usher in a new era of construction productivity. Constr. Res. Innov. 2017, 8, 66-70. [CrossRef]

34. Brand, S. How Buildings Learn: What Happens after They're Built; Viking Press: New York, NY, USA, 1994; ISBN 06708351539780670835157.

35. London Waste and Recycling Board (LWARB). London, the Circular Economy Capital: Towards a Circular Economy-Context and Oppoprtunities. 2015. Available online: http:/ /www.lwarb.gov.uk/what-we-do/ circular-london/towards-a-circular-economy/ (accessed on 11 January 2018).

36. Bell, M. Energy efficiency in existing buildings: The role of building regulations. In COBRA 2004, Proceedings of the RICS Foundation Construction and Building Research Conference, Leeds, UK, 7-8 September 2004; Ellis, R., Bell, M., Eds.; RICS Foundation: London, UK, 2004; p. 16.

37. Hinnells, M.; Boardman, B.; Layberry, R.; Darby, S.; Killip, G. The UK Housing Stock 2005 to 2050: Assumptions used in Scenarios and Sensitivity Analysis in UKDCM2; Environmental Change Institute, University of Oxford: Oxford, UK, 2007.

38. Van der Flier, K.; Thomsen, A. Life cycle of dwellings and demolition by Dutch housing associations. In Sustainable Neighbourhood Transformation; Gruis, V., Visscher, H., Kleinhans, R., Eds.; IOS Press: Delft, The Netherlands, 2006; pp. 23-41, ISBN 9781586037185.

39. Poelman, W.A. Supply Driven Architecture (SDA). In Lifecycle Design of Buildings, Proceedings of the Systems and Materials: CIB W115 Construction Material Stewardship, Enschede, The Netherlands, 12-15 June 2009; 
Durmišević, E., Ed.; International Council for Building Research Studies and Documentation: Rotterdam, The Netherlands, 2009; pp. 110-117.

40. Hammond, G.; Jones, C. Embodied Carbon: The Inventory of Carbon and Energy (ICE). 2011. Available online: https: / www.bsria.co.uk/information-membership/bookshop/publication/embodied-carbon-theinventory-of-carbon-and-energy-ice/ (accessed on 11 January 2018).

41. Ness, D.; Field, M.; Pullen, S. Making better use of what we've got: Stewardship of existing buildings and infrastructure. In Proceedings of the Fabricating Sustainability: The 39th International Architectural Science Association Conference, Wellington, New Zealand, 17-19 November 2005.

42. Giesekam, J.; Barrett, J.R.; Taylor, P. Construction sector views on low carbon building materials. Build. Res. Inf. 2015, 3218, 1-23. [CrossRef]

43. Moffatt, S.; Russell, P. Assessing Buildings for Adaptability: Annex 31, Energy-Related Environmental Impact of Buildings. 2001. Available online: http://www.iea-ebc.org/Data/publications/EBC_Annex_31_ Assessing_Building.pdf (accessed on 11 January 2018).

44. Bowes, H.; Golton, B. Obsolescence and demolition of local authority dwellings in the UK-A case study. In Deconstruction and Materials Reuse: Technology, Economics and Policy; CIB Publication 266 CIB Task Group 39: Deconstruction Meeting; Chini, A., Ed.; International Council for Research and Innovation in Building and Construction (CIB): Wellington, New Zealand, 2001; pp. 87-97.

45. Thomsen, A.; van der Flier, K. Replacement or renovation of dwellings: The relevance of a more sustainable approach. Build. Res. Inf. 2009, 37, 649-659. [CrossRef]

46. Power, A. Housing and sustainability: Demolition or refurbishment? Proc. ICE Urban Des. Plan. 2010, 163, 205-216. [CrossRef]

47. Thomsen, A.; van der Flier, K. Understanding obsolescence: A conceptual model for buildings. Build. Res. Inf. 2011, 39, 352-362. [CrossRef]

48. Crawford, K.; Johnson, C.; Davies, F.; Joo, S.; Bell, S. Demolition or Refurbishment of Social Housing? A Review of the Evidence; Just Space and the London Tenants Federation: London, UK, 2014.

49. Iacovidou, E.; Purnell, P. Mining the physical infrastructure: Opportunities, barriers and interventions in promoting structural components reuse. Sci. Total Environ. 2016, 557-558, 791-807. [CrossRef] [PubMed]

50. Nixon, P.J. The use of materials from demolition in construction. Resour. Policy 1976, 2, 276-283. [CrossRef]

51. BigREc Survey: A Survey of the UK Reclamation and Salvage Trade. 2007. Available online: http:/ / www. wrap.org.uk/sites/files/wrap/BigREcSurveyreport.pdf (accessed on 11 January 2018).

52. Sassi, P. Designing buildings to close the material resource loop. Proc. ICE Eng. Sustain. 2004, 157, $163-171$. [CrossRef]

53. Sassi, P. Study of current building methods that enable the dismantling of building structures and their classifications according to their ability to be reused, recycled or downcycled. In Proceedings of the International Conference for Sustainable Building, Oslo, Norway, 23-25 September 2002.

54. Hemström, K.; Palm, D.; Lindblom, J.; Vegas, I.J.; Lisbona, A.; Horckmans, L.; Ratman-kłosińska, I. Characterisation of supply chain for reused building components in Europe. In Proceedings of the Eighth International Conference on the Environmental and Technical Implications of Construction with Alternative Materials (WASCON 2012), Gothenburg, Sweden, 30 May-1 June 2012; Arm, M., Vandecasteele, C., Heynen, J., Suer, P., Lind, B., Eds.; The International Society for the Environmental and Technical Implications of Construction with Alternative Materials (ISCOWA): Gothenburg, Sweden, 2012; pp. 1-6.

55. Gorgolewski, M. The recycled building project. In Sustainable Building; Aeneas: Maastricht, The Netherlands, 2000.

56. Jones, K.; Stegemann, J.; Sykes, J.; Winslow, P. Adoption of unconventional approaches in construction: The case of cross-laminated timber. Constr. Build. Mater. 2016, 125, 690-702. [CrossRef]

57. Gorgolewski, M. Designing with reused building components: Some challenges. Build. Res. Inf. 2008, 36, 175-188. [CrossRef]

58. Geyer, R.; Jackson, T. Supply loops and their constraints: The industrial ecology of recycling and reuse. Calif. Manag. Rev. 2004, 46, 55-73. [CrossRef]

59. Chileshe, N.; Rameezdeen, R.; Hosseini, M.R.; Lehmann, S. Barriers to implementing reverse logistics in South Australian construction organisations. Supply Chain Manag. Int. J. 2015, 20, 179-204. [CrossRef]

60. Chong, W.K.; Hermreck, C. Understanding transportation energy and technical metabolism of construction waste recycling. Resour. Conserv. Recycl. 2010, 54, 579-590. [CrossRef] 
61. Gustavsson, L.; Sathre, R. Variability in energy and carbon dioxide balances of wood and concrete building materials. Build. Environ. 2006, 41, 940-951. [CrossRef]

62. Nixon, P.J. Recycled concrete as an aggregate for concrete-A review. Matériaux Constr. 1978, 11, 371-378. [CrossRef]

63. Silva, R.V.; De Brito, J.; Dhir, R.K. Properties and composition of recycled aggregates from construction and demolition waste suitable for concrete production. Constr. Build. Mater. 2014, 65, 201-217. [CrossRef]

64. Hradil, P.; Talja, A.; Wahlstr, M.; Huuhka, S.; Lahdensivu, J.; Pikkuvirta, J. Re-Use of Structural Elements: Environmentally Efficient Recovery of Building Components. 2014. Available online: http:/ /www.vtt.fi/ $\mathrm{inf} / \mathrm{pdf} /$ technology/2014/T200.pdf (accessed on 11 January 2018).

65. Huuhka, S.; Kaasalainen, T.; Hakanen, J.H.; Lahdensivu, J. Reusing concrete panels from buildings for building: Potential in Finnish 1970s mass housing. Resourc. Conserv. Recycl. 2015, 101, 105-121. [CrossRef]

66. Allwood, J.M.; Cullen, J.M.; Carruth, M.A.; Cooper, D.R.; McBrien, M.; Milford, R.L.; Moynihan, M.C.; Patel, A.C.H. Sustainable Materials: With Both Eyes Open; UIT Cambridge Limited: Cambridge, UK, 2012; pp. 222-230, ISBN 978-1-906860-05-9.

67. Cooper, D.R.; Allwood, J.M. Reusing steel and aluminum components at end of product life. Environ. Sci. Technol. 2012, 46, 10334-10340. [CrossRef] [PubMed]

68. Densley Tingley, D.; Cooper, S.; Cullen, J. Understanding and overcoming the barriers to structural steel reuse, a UK perspective. J. Clean. Prod. 2017, 148, 642-652. [CrossRef]

69. Dunant, C.F.; Drewniok, M.P.; Sansom, M.; Corbey, S.; Allwood, J.M.; Cullen, J.M. Real and perceived barriers to steel reuse across the UK construction value chain. Resour. Conserv. Recycl. 2017, 126, 118-131. [CrossRef]

70. Pongiglione, M.; Calderini, C. Material savings through structural steel reuse: A case study in Genoa. Resour. Conserv. Recycl. 2014, 86, 87-92. [CrossRef]

71. Drewniok, M.P.; Dunant, C.F.; Allwood, J.M.; Cullen, J.M. Successful steel reuse in the UK-Key aspects why it happened. In Proceedings of the HISER International Conference on Advances in Recycling and Management of Construction and Demolition Waste, Delft, The Netherlands, 21-23 June 2017; Maio, F., Di Lotfi, S., Bakker, M., Hu, M., Vahidi, A., Eds.; TU Delft Library: Delft, The Netherlands, 2017; pp. 331-334.

72. Fujita, M.; Iwata, M. Reuse system of building steel structures. Struct. Infrastruct. Eng. 2008, 4, $207-220$. [CrossRef]

73. Gorgolewski, M.; Straka, V.; Edmonds, J.; Sergio, C. Facilitating Greater Reuse and Recycling of Structural Steel in the Construction and Demolition Process. 2006. Available online: http:/ / www.nrcan.gc.ca/sites/ www.nrcan.gc.ca/files/mineralsmetals/pdf/mms-smm/busi-indu/rad-rad/pdf/re-ste-fin-eng.pdf (accessed on 16 January 2018).

74. Kay, T. “Reiner Pilz”. Salvo Monthly. 11 October 1994, pp. 11-14. Available online: http:/ / www.nrutech. com/wp-content/uploads/2014/09/1994_Salvo_Reiner_Pilz_Upcycling.pdf (accessed on 16 January 2018).

75. Allwood, J.M.; Ashby, M.F.; Gutowski, T.G.; Worrell, E. Material efficiency: A white paper. Resour. Conserv. Recycl. 2011, 55, 362-381. [CrossRef]

76. Sung, K. A Review on upcycling: Current body of literature, knowledge gaps and a way forward. In Proceedings of the ICECESS 2015: 17th International Conference on Environmental, Cultural, Economic and Social Sustainability, Venice, Italy, 13-14 April 2015; Volume 17, pp. 28-40.

77. Baker-Brown, D. The Re-Use Atlas: A Designer's Guide Towards a Circular Economy; RIBA Publishing: London, UK, 2017; ISBN 1859466443.

78. Nielsen, S. Final Report: Nordic Built Component Reuse. 2016. Available online: http:/ /vandkunsten.com/ wp-content/uploads/2016/10/NBCR-20161013-web.pdf (accessed on 11 January 2018).

79. Baker-Brown, D. Developing the Brighton Waste House: From zero waste on site to re-use of waste. In Proceedings of the International Conference on Sustainable Built Environment Developing, Hamburg, Germany, 7-11 March 2016; pp. 342-351.

80. Geels, F.W. Technological transitions as evolutionary reconfiguration processes: A multi-level perspective and a case-study. Res. Policy 2002, 31, 1257-1274. [CrossRef]

81. Liu, C.; Pun, S.K.; Itoh, Y. Information technology applications for planning in deconstruction. In Designing, Managing and Supporting Construction Projects through Innovation and IT Solutions, Proceedings of the World IT Conference for Design and Construction (INCITE 2004), Langkawi, Malaysia, 18-24 February 2004; Construction Industry Development Board: Kuala Lumpur, Malaysia, 2004; pp. 97-102. 
82. Pun, S.K.; Liu, C.; Treloar, G.; Langston, C.; Itoh, Y. Development of a web-based information system for cascading utilisation of construction materials. In Aubea 2003: Working Together: Proceedings of the 28th Annual Conference of the Australasian Universities Building Educators Association; Deakin University: Geelong, Victoria, 2003; pp. 293-300.

83. Pun, S.K.; Liu, C.; Langston, C.; Treloar, G. Electronic Waste Exchange for Just-in-Time Building Demolition. Int. J. Constr. Manag. 2007, 7, 65-77. [CrossRef]

84. Pun, S.K.; Liu, C. A Framework for Material Management in the Building Demolition Industry. Archit. Sci. Rev. 2006, 49, 391-398. [CrossRef]

85. Hurley, J.W. Valuing the pre-demolition audit process. In Proceedings of the 11th Rinker International Conference on Deconstruction and Materials Reuse, Gainesville, FL, USA, 7-10 May 2003; Chini, A.R., Ed.; International Council for Research and Innovation in Building and Construction (CIB): Rotterdam, The Netherlands, 2003; pp. 151-164.

86. Chen, Z.; Li, H.; Kong, S.C.W.; Hong, J.; Xu, Q. E-commerce system simulation for construction and demolition waste exchange. Autom. Constr. 2006, 15, 706-718. [CrossRef]

87. Ali, A.K. Re-Defining the Architectural Design Process through Building a Decision Support Framework for Design with Reused Building Materials and Components. Ph.D. Thesis, Virginia Polytechnic Institute and State University, Blacksburg, VA, USA, 2012.

88. Ratman-Kłosińska, I. Reducing by reusing-A demo of a Stock-Exchange service for C\&DW recovered elements. In Final Conference of the IRCOW Project (Innovative Strategies for High-Grade Material Recovery from Construction and Demolition Waste); European Commission: Brussels, Belgium, 2013.

89. Looney, J.H. Long term whole life cycle perspectives-Cradle to Cradle and BIM to DRIM. In Steel and the Circular Economy: Steel Reuse and Design for Deconstruction; Steel Construction Institute: London, UK, 2016.

90. Akinade, O.O.; Oyedele, L.O.; Omoteso, K.; Ajayi, S.O.; Bilal, M.; Owolabi, H.A.; Alaka, H.A.; Ayris, L.; Henry Looney, J. BIM-based deconstruction tool: Towards essential functionalities. Int. J. Sustain. Built Environ. 2017, 6, 260-271. [CrossRef]

91. Enviromate Reuse Marketplace. Available online: https://www.enviromate.co.uk/marketplace (accessed on 4 October 2017).

92. Resource Efficient Scotland Construction Materials Exchange: Search for Surplus Materials in Your Area. Available online: http: / / cme.resourceefficientscotland.com/ (accessed on 1 October 2017).

93. Loop The Circular Economy Platform for the Built Environment. Available online: http://loop-hub.co.uk/ (accessed on 1 October 2017).

94. Salvo Materials Information Exchange. Available online: http://salvomie.co.uk/ (accessed on 1 October 2017).

95. Trade Leftovers Don't Skip It—List It! Swap Spare and Surplus Building Supplies. Available online: http:/ / www.tradeleftovers.com/ (accessed on 1 October 2017).

96. Danermark, B.; Ekstrom, M.; Jakobsen, L.; Karlsson, J.C. Explaining Society: Critical Realism in the Social Sciences; Taylor \& Francis e-Library: London, UK; New York, NY, USA, 2005; ISBN 0203996240.

97. Denzin, N.K. The Research Act: A Theoretical Introduction to Sociological Methods; Methodological Perspectives; Aldine Transaction: New Brunswick, NJ, USA, 2009; pp. 297-313, ISBN 9780202362489.

98. Yin, R.K. Case Study Research: Design and Methods, 5th ed.; SAGE Publications: Thousand Oaks, CA, USA, 2014; pp. 103-132, ISBN 978-1-4522-4256-9.

99. McCracken, G. The Long Interview; SAGE Publications: Newbury Park, CA, USA, 1988; Volume 13, ISBN 978-0803933538.

100. Martin, J.N. The seven samurai of systems engineering: Dealing with the complexity of 7 interrelated systems. In Proceedings of the Fourteenth Annual International Symposium of the International Council on Systems Engineering (INCOSE), Toulouse, France, 20-24 June 2004; John Wiley \& Sons, Ltd.: Toulouse, France, 2004; Volume 14, pp. 459-470.

101. NFDC/IDE. Demolition and Refurbishment: Resource Protocol. Hemel Hempstead. 2016. Available online: http:/ / demolition-nfdc.com/files/en/group/download/file/76_nfdcpredemolitionbrochurefinal.pdf (accessed on 11 January 2018).

102. European Commission. Commission Decision of 3 May 2000 Replacing Decision 94/3/EC Establishing a List of Wastes Pursuant to Article 1(a) of Council Directive 75/442/EEC on Waste (European Waste Catalogue); European Commission: Brussels, Belgium, 2000; pp. 1-31. 
103. BioRegional Development Group. Reuse and Recycling on the London 2012 Olympic Park: Lessons for Demolition, Construction and Regeneration; BioRegional Development Group: Wallington, UK, 2011.

104. European Commission. Regulation (EC) No 2150/2002 of the European Parliament and of the Council of 25 November 2002 on Waste Statistics; European Commission: Brussels, Belgium, 2002; pp. 1-45.

105. Carris, J. Learning Legacy: Demolition Waste Management on the Olympic Park; London Organising Committee of the Olympic Games and Paralympic Games Limited: London, UK, 2011.

106. McGinley, T. JunkUp: Supporting e-procurement of used materials in the construction industry using eBay and BIM. In Proceedings of the Unmaking Waste 2015, Adelaide, South Australia, 22-24 May 2015; pp. 241-251.

107. Kay, T.; Essex, J. Pushing Reuse: Towards a Low-Carbon Construction Industry; BioRegional: Wallington, UK, 2010.

108. Van Ewijk, S.; Stegemann, J.A. Limitations of the waste hierarchy for achieving absolute reductions in material throughput. J. Clean. Prod. 2016, 132, 122-128. [CrossRef]

109. The Great Recovery-RSA. Report: North Sea Oil and Gas Rig Decommissioning and Re-use Opportunity. 2015. Available online: https:/ / www.thersa.org/discover/publications-and-articles/reports/north-seaoil-and-gas (accessed on 11 January 2018).

110. Adams, K.T.; Osmani, M.; Thorpe, T.; Thornback, J. Circular economy in construction: Current awareness, challenges and enablers. Proc. Inst. Civ. Eng. Waste Resour. Manag. 2017, 170, 15-24. [CrossRef]

111. Dahlbo, H.; Bachér, J.; Lähtinen, K.; Jouttijärvi, T.; Suoheimo, P.; Mattila, T.; Sironen, S.; Myllymaa, T.; Saramäki, K. Construction and demolition waste management-A holistic evaluation of environmental performance. J. Clean. Prod. 2015, 107, 333-341. [CrossRef]

112. Zou, P.; Hardy, R.; Yang, R. Barriers to building and construction waste reduction, reuse and recycling: A case study of the Australian Capital Region. In Building Today-Saving Tomorrow, Proceedings of the Sustainability In Construction and Deconstruction, Auckland, New Zealand, 15-17 July 2015; Panko, M., Kestle, L., Eds.; Unitec Institute of Technology: Auckland, New Zealand, 2015; pp. 27-35.

113. Chini, A.; Bruening, S. Deconstruction and materials reuse in the United States. In The Future of Sustainable Construction; IeJC: Gainesville, FL, USA, 2003; pp. 1-22, ISBN 1886431094.

114. McKinsey Global Institute. Resource Revolution: Meeting the World's Energy, Materials, Food, and Water Needs. 2011. Available online: https://www.mckinsey.com/business-functions/sustainabilityand-resource-productivity / our-insights/resource-revolution (accessed on 11 January 2018).

115. Robert, K.-H.; Schmidt-Bleek, B.; Aloisi de Larderel, J.; Basile, G.; Jansen, J.L.; Kuehr, R.; Price Thomas, P.; Suzuki, M.; Hawken, P.; Wackernagel, M. Strategic sustainable development-Selection, design and synergies of applied tools. J. Clean. Prod. 2002, 10, 197-214. [CrossRef]

116. Antosiewicz, M.; Lewandowski, P.; Witajewski-Baltvilks, J. Input vs. output taxation-A DSGE approach to modelling resource decoupling. Sustainability 2016, 8, 1-17. [CrossRef]

117. European Commission. Communication from the Commission to the European Parliament, the Council, the European Economic and Social Committe and the Committee of the Regions: Roadmap to a Resource Efficient Europe; European Commission: Brussels, Belgium, 2011; pp. 1-25.

118. Nakajima, N. A Vision of Industrial Ecology: State-of-the-Art Practices for a Circular and Service-Based Economy. Bull. Sci. Technol. Soc. 2000, 20, 54-69. [CrossRef]

119. Allwood, J.M.; Cullen, J.M.; Milford, R.L. Options for achieving a 50\% cut in industrial carbon emissions by 2050. Environ. Sci. Technol. 2010, 44, 1888-1894. [CrossRef] [PubMed]

120. Stahel, W.R. Policy for material efficiency—Sustainable taxation as a departure from the throwaway society. Philos. Trans. A Math. Phys. Eng. Sci. 2013, 371, 20110567. [CrossRef] [PubMed]

121. Wijkman, A.; Skånberg, K. The Circular Economy and Benefits for Society: Jobs and Climate Clear Winners in an Economy Based on Renewable Energy and Resource Efficiency. 2015. Available online: https: / / www.clubofrome.org/wp-content/uploads/2016/03/The-Circular-Economy-and-Benefits-for-Society.pdf (accessed on 16 January 2018).

(C) 2018 by the authors. Licensee MDPI, Basel, Switzerland. This article is an open access article distributed under the terms and conditions of the Creative Commons Attribution (CC BY) license (http:// creativecommons.org/licenses/by/4.0/). 